\title{
FAKTOR YANG BERHUBUNGAN DENGAN KELELAHAN KERJA PERAWAT DI RUMAH SAKIT PERMATA HATI DURI KECAMATAN MANDAU KABUPATEN BENGKALIS TAHUN 2019
}

\author{
Octa Dwienda ${ }^{1}$, Ahmad Satria ${ }^{2}$, Leni Marfitri ${ }^{3}$. \\ STIKes Hang Tuah Pekanbaru. \\ Email : octadwienda@htp.ac.id
}

\begin{abstract}
Work fatigue is part of a common problem that is often encountered in the workforce. Work fatigue is a symptom related to work efficiency, skills, boredom, and increased anxiety. From the initial survey of interviews and observations conducted, information was obtained that nurses who worked at Permata Hati Duri Hospital often complained of work fatigue The research method used was quantitative with cross sectional design. This research was conducted at Permata Hati Duri Hospital in June-July 2019. The research sample was 66 respondents. Data collection techniques using a questionnaire. The results showed there was no gender relationship ( $p$ value $=0.523)$, there was no relationship between nutritional status ( $p$ value 0.523), there was no history of disease relationship ( $p$ value 0.940), and there was an age relationship ( $p$ value $=0.000)$, status marriage ( $p$ value 0,000 ), years of service ( $p$ value 0.048), work shifts ( $p$ value 0,048) with nurse work fatigue. It is recommended that nurses should do sufficient circumstance after work to maintain the physical and mental condition of the body, to reduce fatigue nurses can do refreshing during holidays. For the hospital, management is expected to be able to take part in training related to efforts to prevent work fatigue by minimizing factors that can influence the occurrence of work fatigue.
\end{abstract}

Keywords : Use of Nurse fatigue, work period, work shift, nutritional status, history of illness 


\section{PENDAHULUAN}

Kelelahan kerja merupakan bagian dari permasalahan umum yang sering dijumpai pada tenaga kerja. Kelelahan kerja adalah gejala yang berhubungan dengan efisiensi kerja, keterampilan, kebosanan, serta peningkatan kecemasan. Kata "lelah" memiliki arti tersendiri bagi setiap individu dan bersifat subjektif (Watania, 2018). Beberapa penelitian menunjukkan bahwa kelelahan memberikan kontribusi yang signifikan terhadap kecelakaan kerja yang dapat terjadi dikarenakan human errors, stress kerja dan penyakit akibat kerja (Pratiwi, 2017).

Menurut Setyawati (2013) kelelahan kerja tidak dapat didefinisikan dengan secara jelas tetapi dapat dirasakan sebagai perasaan kelelahan kerja disertai dengan adanya perubahan waktu reaksi yang menonjol maka indikator perasaan kelelahan kerja dan waktu reaksi dapat dipergunakan untuk mengetahui adanya kelelahan kerja. Perasaan kelelahan kerja adalah gejala yang dikeluhkan pekerja yang merupakan semua perasaan yang tidak menyenangkan. Menurut Permatasari (2017), kelelahan kerja terus menerus akan dapat menimbulkan masalah pada kesehatan dan dapat menggangu fungsi mekanisme dalam tubuh sehingga dapat menyebabkan beberapa penyakit seperti anemia, tiroid dan depresi. Penyakit tersebut adalah penyakit yang timbul akibat kelelahan kerja.

Di balai pengobatan umum ataupun rumah sakit, sekitar 20-40\% pekerja mengeluhkan kelelahan kerja yang berat, yang merupakan gejala dari perasaan lelah kerja (Setyawati, 2010). Apabila kelelahan kerja tidak segera ditangani dan segera beristirahat, maka akan terjadi akumulasi kelelahan dalam sehari, sehingga dapat berdampak lebih parah terhadap kesehatan. Menurut Tarwaka (2010), bahwa risiko dari kelelahan kerja yaitu: motivasi kerja menurun, performansi rendah, kualitas kerja rendah, banyak terjadi kesalahan, produktivitas kerja rendah, stress akibat kerja, penyakit akibat kerja, cedera, dan terjadi kecelakaan kerja. Sedangkan menurut Setyawati (2013), bahwa dampak dari kelelahan kerja adalah prestasi kerja menurun, badan terasa tidak enak, semangat kerja menurun, dan menurunkan produktivitas kerja.

Kelelahan menunjukkan keadaan fisik dan mental yang berbeda, tetapi semuanya berakibat kepada penurunan daya kerja dan berkurangnya ketahanan tubuh untuk bekerja. Terdapat dua jenis kelelahan, yaitu kelelahan otot dan kelelahan umum. Kelelahan otot ditandai Antara lain oleh tremor atau rasa nyeri 
yang terdapat pada otot, sedangkan kelelahan umum ditunjukkan oleh hilangnya kemauan untuk bekerja yang penyebabnya adalah keadaan persarafan sentral atau kondisi psikispsikologis (Suma'mur, 2013)

Di dalam proses kerja, banyaknya faktor-faktor yang dapat menjadi pencetus timbulnya kelelahan kerja, faktor-faktor penyebab tersebut antara lain menurut Budiono (2015) yaitu intensitas dan lamanya kerja, status kesehatan, beban kerja dan status gizi.

Di Rumah Sakit, pekerjaan seorang perawat merupakan pekerjaan yang memiliki stress yang tinggi, karena dalam bekerja perawat berhubungan langsung dengan berbagai macam pasien dengan diagnosa penyakit dalam respon yang berbeda-beda (Desima, 2013).

Menurut UU Keperawatan No.38 tahun 2014, perawat adalah seseorang yang telah lulus pendidikan tinggi keperawatan, baik didalam maupun diluar negri yang diakui oleh pemerintah. Menurut Astuti Wiji, 2017, perawat merupakan pekerja pemberi jasa layanan kesehatan yang bertugas untuk membantu pelayanan gawat darurat dan menyediakan pelayanan keperawatan untuk orang sakit, terluka, dan ketidakmampuan fisik dan mental secara terus menerus 24 jam. Berdasarkan laporan World Health Organization
(WHO) ada lebih 9 juta perawat dan bidan di 141 negara. Dari laporan tersebut dapat disimpulkan bahwa profesi perawat dibandingkan dengan profesi lainnya, profesi perawat memegang peranan sangat besar.

Berdasarkan hasil penelitian yang dilakukan oleh Rizky Maharja (2015) menunjukkan bahwa tingkat kelelahan kerja perawat di bangsal rawat inap di RSU Haji Surabaya berhubungan dengan beban kerja fisik, semakin tinggi beban kerja fisik perawat, maka akan semakin tinggi pula tingkat kelelahan yang dialami perawat.

Rumah Sakit Permata Hati Duri Kecamatan Mandau Kabupaten Bengkalis merupakan rumah sakit swasta dengan kelas C. Rumah Sakit Permata Hati sebagai rumah sakit swasta terbesar di Kota Duri sudah selayaknya rumah sakit ini memegang peranan yang sangat penting dalam konteks rujukan. Disamping itu, mengingat kesehatan merupakan kebutuhan ynag sangat penting, maka masyarakat pasti akan menuntut pelayanan kesehatan yang optimal dari institusi pelayanan kesehatan tersebut.

Sementara itu jumlah kunjungan pasien rawat jalan dan rawat inap di Rumah Sakit Permata Hati mencapai angka 8000 pasien perbulan dan untuk 
pasien rawat inap mencapai 600 pasien perbulannya.

Sebagian besar tenaga kerja di Rumah Sakit Permata Hati adalah tenaga keperawatan, dimana perawat yang berpendidikan DIII berjumlah 45 perawat, DIV berjumlah 1 perawat, S1 keperawatan berjumlah 19 perawat dan NERS berjumlah 1 perawat.

Dari survey awal yang dilakukan didapat informasi bahwa perawat yang bekerja di Rumah Sakit Permata Hati Duri sering mengeluhkan kelelahan kerja. Hal ini diperkuat dari hasil wawancara yang dilakukan penulis terhadap 7 orang perawat yang bekerja di Rumah Sakit Permata Hati Duri, perawat sering mengeluh adanya stress terhadap beban kerja, sering merasa kelelahan, dan juga mengeluh terhadap tempat kerja yang berisiko terhadap penularan penyakit yang tinggi. Beberapa perawat juga mengakui alasan pengambilan cuti dikarenakan merasa lelah dengan beban kerja yang tinggi. Berdasarkan dari informasi absensi perawat bahwa beberapa perawat mengalami sakit karena lelah dan izin untuk tidak masuk kerja dengan alasan sakit.

Berdasarkan latar belakang diatas dan observasi yang dilakukan bahwa perawat di Rumah Sakit Permata Hati Duri sering mengeluhkan lelah dikarenakan beban kerja yang tinggi dan dari absensi perawat dapat dilihat bahwa perawat sering izin tidak masuk kerja dengan alasan sakit, adapun permasalahannya yaitu kelelahan kerja yang dialami oleh perawat. Hal ini membuat penulis tertarik untuk melakukan penelitian mengenai "Faktor Yang Berhubungan Dengan Kelelahan Kerja Perawat Di Rumah Sakit Permata Hati Duri Kecamatan Mandau Kabupaten Bengkalis Tahun 2019.

\section{METODE PENELITIAN}

Jenis penelitian ini adalah kuantitatif dengan pendekatan cross sectional yaitu mengetahui hubungan variabel independen dan dependen pada waktu tertentu untuk mengetahui faktor-faktor yang berhubungan dengan kelelahan kerja pada tenaga perawat di Rumah Sakit Permata Hati Duri.

Populasi pada penelitian ini meliputi 66 perawat yang ada di Rumah Sakit Permata Hati Duri Kecamatan Mandau Kabupaten Bengkalis

Sampel penelitian ini adalah seluruh tenaga perawat yang ada di Rumah Sakit Permata Hati Duri Kecamatan Mandau Kabupaten Bengkalis yang berjumlah 66 perawat ditentukan berdasarkan kriteria inklusi dan ekslusi: 
Kriteria Inklusi : kriteria inklusi adalah karakteristik umum dari subjek penelitian yang layak untuk dilakukan atau dijadikan responden. Kriteria inklusi pada penelitian ini adalah : a) perawat yang bekerja di Rumah Sakit Pertama Hati Duri Kecamatan Mandau Kabupaten Bengkalis b) Perawat yang memiliki jam kerja shift (pagi,siang,malam) c) Perawat sebagai pegawai tetap dan honor. Kriteria Eksklusi : a) Perawat yang berperan sebagai kepala ruangan b) Bidan yang bekerja sebagai perawat ruangan.

HASIL DAN PEMBAHASAN

\section{Hubungan Antara Jenis Kelamin Dengan Kelelahan Kerja}

Tabel 1

Hubungan Jenis Kelamin dengan Kelelahan Kerja Perawat

Di Rumah Sakit Permata Hati Duri Kecamatan Mandau

Kabupaten Bengkalis Tahun 2019

\begin{tabular}{|c|c|c|c|c|c|c|c|c|c|}
\hline \multirow{3}{*}{ No } & \multirow{3}{*}{ Variabel uji } & \multicolumn{6}{|c|}{ Kelelahan Kerja } & \multirow{3}{*}{$\begin{array}{c}\mathrm{P} \\
\text { value }\end{array}$} & \multirow{3}{*}{$\begin{array}{c}\text { POR 95\% } \\
\text { CI }\end{array}$} \\
\hline & & \multicolumn{2}{|c|}{ Rendah } & \multicolumn{2}{|c|}{ Tinggi } & \multicolumn{2}{|c|}{ Total } & & \\
\hline & & $\mathbf{N}$ & $\%$ & $\mathbf{n}$ & $\%$ & $\mathbf{N}$ & $\%$ & & \\
\hline \multirow[t]{4}{*}{1} & Jenis kelamin & & & & & & & & \\
\hline & Perempuan & 17 & $33,3 \%$ & 34 & $66,7 \%$ & 51 & $100 \%$ & \multirow{3}{*}{0,000} & \multirow{3}{*}{$\begin{array}{c}0,571 \\
(0,117- \\
1,840)\end{array}$} \\
\hline & Laki-laki & 7 & $46,7 \%$ & 8 & $53,3 \%$ & 15 & $100 \%$ & & \\
\hline & Jumlah & 24 & $36,4 \%$ & 42 & $63,6 \%$ & 66 & $100 \%$ & & \\
\hline
\end{tabular}

\section{Berdasarkan tabel 1 diatas}

diketahui dari 51 responden yang berjenis kelamin perempuan, $34(66,7 \%)$ mengalami kelelahan kerja tinggi. Dari 15 responden yang berjenis kelamin laki- laki, $8(53,3 \%)$ diantaranya mengalami kelelahan tinggi.

Hasil uji statistik menggunakan Chi square diperoleh nilai $\mathrm{P}$ value $=$ $0,523>\mathrm{a}_{0,05}$, maka ha diterima dan ho ditolak, dapat disimpulkan bahwa tidak 
ada hubungan antara jenis kelamin dengan kelelahan kerja perawat di Rumah Sakit Permata Hati Duri Kecamatan Mandau Kabupaten Bengkalis tahun 2019.

Hasil penelitian ini sejalan dengan penelitian Perwitasari (2013) di RSUD dr. Mohammad Soewandhie Surabaya, yang menyatakan yang berjenis kelamin perempuan sebanyak 72 orang mengalami tingkat kelelahan rendah terdapat $32(44,4 \%)$ orang dan yang mengalami tingkat kelelahan tinggi $21(29,2 \%)$ orang dengan uji statistik diperoleh nilai $\mathrm{P}$ value $=0,572<\mathrm{a}_{0,05}$. Sehingga dapat disimpulkan bahwa tidak ada hubungan antara jenis kelamin dengan kelelahan kerja yang dirasakan perawat di RSUD dr. Mohammad Soewandhie Surabaya.

Menurut analisa peneliti, secara umum wanita hanya mempunyai kekuatan fisik 2/3 dari kemampuan fisik atau kekuatan otot laki-laki. Tetapi dalam hal tertentu, wanita lebih teliti daripada laki-laki. Pada penelitian ini, jenis kelamin tidak berhubungan dengan kelelahan kerja perawat, namun tidak adanya hubungan ini memiliki arti bahwa banyak faktor yang mempengaruhi kelelahan dan jenis kelamin bukan faktor yang berhubungan secara langsung dengan terjadinya kelelahan.

\section{Hubungan Antara Jenis Usia Dengan Kelelahan Kerja}

Tabel 2

Hubungan Usia dengan Kelelahan Kerja Perawat

Di Rumah Sakit Permata Hati Duri Kecamatan Mandau

Kabupaten Bengkalis Tahun 2019

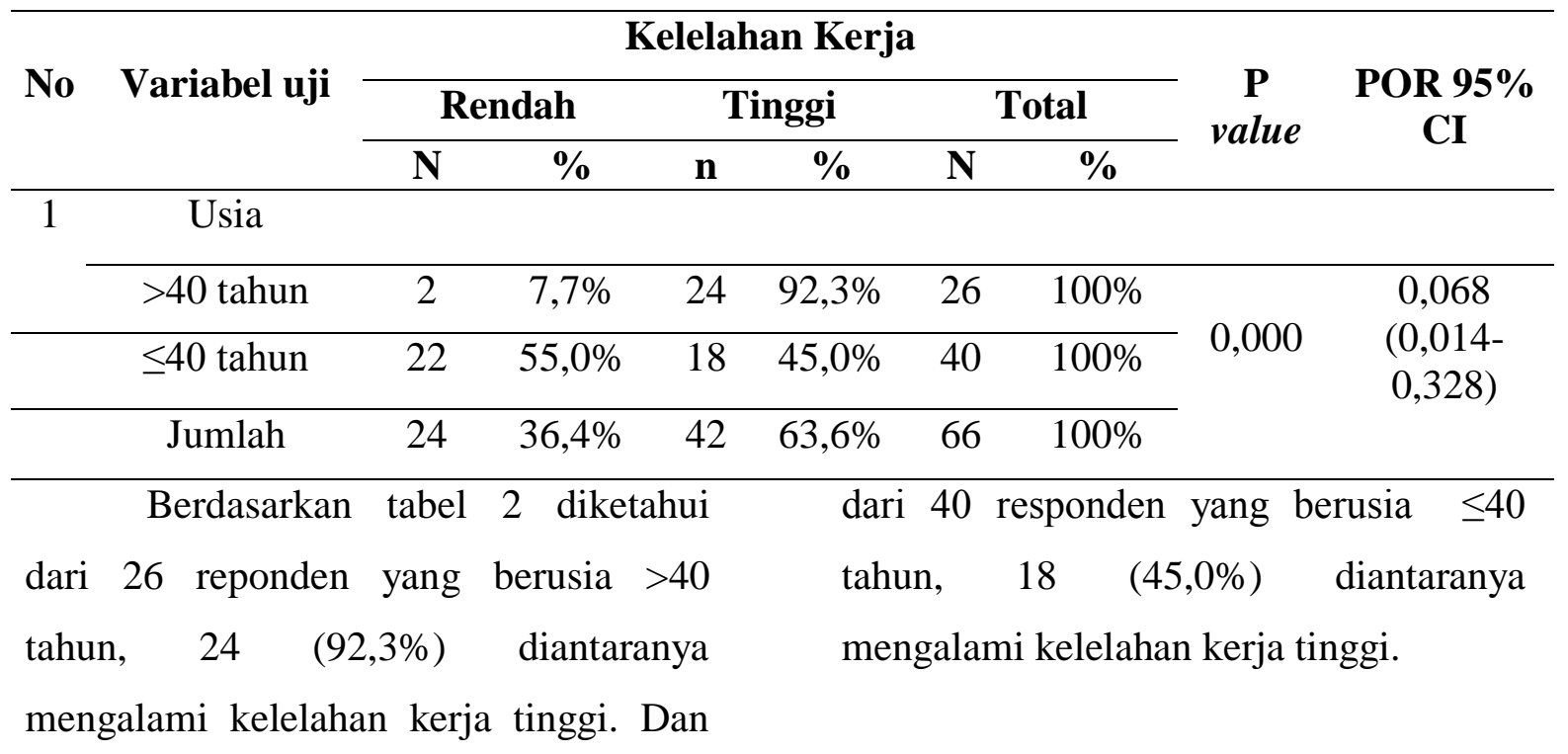


Hasil uji statistik menggunakan Chi square diperoleh nilai $\mathrm{P}$ value = $0,000<\mathrm{a}_{0,05}$, maka ha ditolak dan ho diterima, dapat disimpulkan bahwa terdapat hubungan yang bermakna antara usia dengan kelelahan kerja perawat di Rumah Sakit Permata Hati Duri Kecamatan Mandau Kabupaten Bengkalis tahun 2019. Dari hasil analisis diperoleh $\mathrm{POR}=0,068<1$. Artinya responden dengan usia >40 tahun, berisiko 0,06 kali mengalami kelelahan kerja dibandingkan responden $\leq 40$ tahun.
Hasil penelitian ini sejalan dengan penelitian Gandhiwu (2013), dimana hasil penelitian menunjukkan $\mathrm{P}$ value $=0,000<\mathrm{a}_{0,05}$, yang berarti ada hubungan antara usia dengan kelelahan kerja.

Menurut analisa peneliti bahwa setiap perawat merasa kelelahan yang berhubungan dengan faktor umur pekerja. perawat yang berumur diatas 40 akan merasa lebih mudah lelah.

\section{Hubungan Antara Status Perkawinan Dengan Kelelahan Kerja}

Tabel 3

Hubungan Status Perkawinan dengan Kelelahan Kerja Perawat

Di Rumah Sakit Permata Hati Duri Kecamatan Mandau

Kabupaten Bengkalis Tahun 2019

\begin{tabular}{|c|c|c|c|c|c|c|c|c|c|}
\hline \multirow{3}{*}{ No } & \multirow{3}{*}{ Variabel uji } & \multicolumn{6}{|c|}{ Kelelahan Kerja } & \multirow{3}{*}{ P value } & \multirow{3}{*}{$\begin{array}{c}\text { POR 95\% } \\
\text { CI }\end{array}$} \\
\hline & & \multicolumn{2}{|c|}{ Rendah } & \multicolumn{2}{|c|}{ Tinggi } & \multicolumn{2}{|c|}{ Total } & & \\
\hline & & $\mathbf{N}$ & $\%$ & $\mathbf{n}$ & $\%$ & $\mathbf{N}$ & $\%$ & & \\
\hline \multirow[t]{3}{*}{1} & $\begin{array}{c}\text { Status } \\
\text { Perkawinan }\end{array}$ & & & & & & & & \\
\hline & kawin & 11 & $21,6 \%$ & 40 & $78,4 \%$ & 51 & $100 \%$ & \multirow{2}{*}{0,000} & 0,042 \\
\hline & Tidak kawin & 13 & $86,7 \%$ & 2 & $13,3 \%$ & 15 & $100 \%$ & & $0,216)$ \\
\hline & Jumlah & 24 & $36,4 \%$ & 42 & $63,6 \%$ & 66 & $100 \%$ & & \\
\hline
\end{tabular}

Chi square diperoleh nilai $\mathrm{P}$ value $=0,000$

Berdasarkan tabel 3 diatas, diketahui dari 51 responden yang berstatus kawin, $40 \quad(78,4 \%)$ diantaranya mengalami kelelahan kerja tinggi. Dari 15 responden yang berstatus tidak kawin, 2 (13,3\%) diantaranya mengalami kelelahan kerja tinggi.

Hasil uji statistik menggunakan

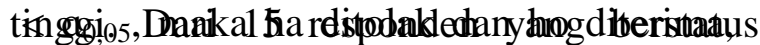

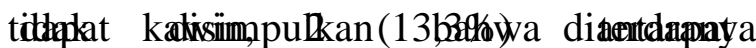
hebgymgani lyeltegahlaørkeafjandinggiara status perkawinan dengan kelelahan kerja perawat di Rumah Sakit Permata Hati Duri Kecamatan Mandau Kabupaten Bengkalis tahun 2019. Dari hasil analisis diperoleh $\mathrm{POR}=0,042<1$. Artinya 
responden dengan status kawin, berisiko 0,04 kali mengalami kelelahan kerja dibandingkan responden dengan status tidak kawin.

Hasil uji statistik menggunakan Chi square diperoleh nilai $\mathrm{P}$ value $=0,000$ $<\mathrm{a}_{0,05}$, maka ha ditolak dan ho diterima, dapat disimpulkan bahwa terdapat hubungan yang bermakna antara status perkawinan dengan kelelahan kerja perawat di Rumah Sakit Permata Hati Duri Kecamatan Mandau Kabupaten Bengkalis tahun 2019. Dari hasil analisis diperoleh $\mathrm{POR}=0,042<1$. Artinya responden dengan status kawin, berisiko 0,04 kali mengalami kelelahan kerja dibandingkan responden dengan status tidak kawin.

Hasil penelitian ini sejalan dengan penelitian Maharaja (2015), menunjukkan sebagian responden sudah menikah sebanyak $21(77,78 \%)$ responden yang berstatus suah menikah mengalami kelelahan kerja. Status sudah menikah ini menjadikan perawat memiliki beban tambahan selain beban utama dari pekerjaan keperawatan.

Menurut analisa peneliti pernikahan menyebabkan meningkatnya tanggung jawab yang dapat membuat pekerjaan tetap lebih berharga dan penting. Seseorang yang sudah menikah memiliki tugas-tugas seperti belajar hidup dengan pengalaman perkawinan, mulai hidup berkeluarga, memelihara anak, mengatur rumah tangga. Sehingga seseorang yang sudah menikah akan mengalami kelelahan kerja akibat peran sebagai perawat dan peran sebagai istri/ibu dirumah.

\section{Hubungan Antara Masa Kerja Dengan Kelelahan Kerja}

Table 4

Hubungan Masa Kerja dengan Kelelahan Kerja Perawat

Di Rumah Sakit Permata Hati Duri Kecamatan Mandau

Kabupaten Bengkalis Tahun 2019

\begin{tabular}{|c|c|c|c|c|c|c|c|c|c|}
\hline \multirow{3}{*}{ No } & \multirow{3}{*}{ Variabel uji } & \multicolumn{6}{|c|}{ Kelelahan Kerja } & \multirow{3}{*}{$\begin{array}{c}\mathrm{P} \\
\text { value }\end{array}$} & \multirow{3}{*}{$\begin{array}{c}\text { POR } \\
95 \% \text { CI }\end{array}$} \\
\hline & & \multicolumn{2}{|c|}{ Rendah } & \multicolumn{2}{|c|}{ Tinggi } & \multicolumn{2}{|c|}{ Total } & & \\
\hline & & $\mathbf{N}$ & $\%$ & $\mathbf{n}$ & $\%$ & $\mathbf{N}$ & $\%$ & & \\
\hline \multirow[t]{4}{*}{1} & Masa Kerja & & & & & & & & \\
\hline & $>10$ tahun & 8 & $23,5 \%$ & 26 & $76,5 \%$ & 34 & $100 \%$ & \multirow{3}{*}{0,048} & \multirow{3}{*}{$\begin{array}{c}0,308 \\
(0,107- \\
0,882)\end{array}$} \\
\hline & $\leq 10$ tahun & 16 & $55,0 \%$ & 16 & $50,0 \%$ & 32 & $100 \%$ & & \\
\hline & Jumlah & 24 & $36,4 \%$ & 42 & $63,6 \%$ & 66 & $100 \%$ & & \\
\hline
\end{tabular}


Berdasarkan tabel 4 diatas, diketahui dari 34 responden yang memiliki masa kerja >10 tahun, 26 $(76,5 \%)$ diantaranya mengalami kelelahan kerja tinggi. Dari 32 responden yang memiliki masa kerja $\leq 10$ tahun, 16 $(55,0 \%)$ diantaranya mengalami kelelahan kerja tinggi.

Hasil uji statistik menggunakan Chi square diperoleh nilai $\mathrm{P}$ value $=0,048$ $<\mathrm{a}_{0,05}$, maka ha ditolak dan ho diterima, dapat disimpulkan bahwa terdapat hubungan yang bermakna antara masa kerja dengan kelelahan kerja perawat di Rumah Sakit Permata Hati Duri Kecamatan Mandau Kabupaten Bengkalis tahun 2019. Dari hasil analisis diperoleh $\mathrm{POR}=0,308<1$. Artinya responden dengan masa kerja $>10$ tahun, berisiko 0,3 kali mengalami kelelahan kerja dibandingkan responden dengan masa kerja $\leq 10$ tahun.

Berdasarkan hasil penelitian Maulina Hariyati (2013) masa kerja minimal 15 tahun dan masa kerja maksimal 30 tahun berdasarkan referensi dapat diketahui masa kerja mempengaruhi kelelahan kerja.

Menurut analisa peneliti bahwa semakin lama masa kerja seseorang maka semakin tinggi tingkat kelelahan yang dialami, karena semakin lama bekerja maka perasaan jenuh atau bosan akibat pekerjaan yang monoton akan berpengaruh terhadap tingkat kelelahan yang dialami.

\section{Hubungan Antara Shift Kerja Dengan Kelelahan Kerja}

Table 5

Hubungan Shift Kerja dengan Kelelahan Kerja Perawat Di Rumah Sakit Permata Hatu Duri Kecamatan Mandau Kabupaten Bengkalis Tahun 2019

\begin{tabular}{|c|c|c|c|c|c|c|c|c|c|}
\hline \multirow{3}{*}{ No } & \multirow{3}{*}{$\begin{array}{c}\text { Variabel } \\
\text { uji }\end{array}$} & \multicolumn{6}{|c|}{ Kelelahan Kerja } & \multirow{3}{*}{$\begin{array}{c}\mathbf{P} \\
\text { value }\end{array}$} & \multirow{3}{*}{$\begin{array}{c}\text { POR } \\
95 \% \text { CI }\end{array}$} \\
\hline & & \multicolumn{2}{|c|}{ Rendah } & \multicolumn{2}{|c|}{ Tinggi } & \multicolumn{2}{|c|}{ Total } & & \\
\hline & & $\mathbf{N}$ & $\%$ & $\mathbf{n}$ & $\%$ & $\mathbf{N}$ & $\%$ & & \\
\hline \multirow[t]{4}{*}{1} & Shift Kerja & & & & & & & & \\
\hline & Beresiko & 11 & $21,6 \%$ & 39 & $78,0 \%$ & 50 & $100 \%$ & \multirow{3}{*}{0,000} & \multirow{3}{*}{$\begin{array}{c}0,042 \\
(0,008- \\
0,216)\end{array}$} \\
\hline & $\begin{array}{c}\text { Tidak } \\
\text { beresiko }\end{array}$ & 13 & $86,7 \%$ & 3 & $18,8 \%$ & 15 & $100 \%$ & & \\
\hline & Jumlah & 24 & $36,4 \%$ & 42 & $63,6 \%$ & 66 & $100 \%$ & & \\
\hline
\end{tabular}

Berdasarkan tabel 5 diatas, diketahui 50 responden yang memiliki shift kerja beresiko, $39 \quad(78,0 \%)$ diantaranya mengalami kelelahan kerja tinggi. Dari 15 responden yang memiliki shift kerja tidak beresiko, 3 (18,8\%) diantaranya mengalami kelelahan kerja tinggi.

Hasil uji statistik menggunakan $C h i$ square diperoleh nilai $\mathrm{P}$ value $=0,000<$ 
$\mathrm{a}_{0,05}$, maka ha ditolak dan ho diterima, dapat disimpulkan bahwa terdapat hubungan yang bermakna antara shift kerja dengan kelelahan kerja perawat di Rumah Sakit Permata Hati Duri Kecamatan Mandau Kabupaten Bengkalis tahun 2019. Dari hasil analisis diperoleh POR $=0,041<1$. Artinya responden dengan shift beresiko, berisiko 0,4 kali mengalami kelelahan kerja dibandingkan responden shift tidak beresiko.

Berdasarkan hasil penelitian Angouw (2016), penelitian dengan menggunakan analisis Chi square antara kelelahan kerja pada shift kerja pagi, siang, malam didapatkan nilai $\mathrm{P}$ value $=0,000$. Hasil ini menunjukkan bahwa adanya perbedaan tingkat kelelahan melalui shift kerja perawat.

Menurut analisa peneliti bahwa pekerja yang bekerja dengan shift mengalami kelelahan kerja yang berbedabeda. Pekerja pada shift beresiko yaitu malam dan siang mengalami kelelahan kerja yang tinggi.

\section{Hubungan Antara Status Gizi Dengan Kelelahan Kerja}

Tabel 6

Hubungan Status Gizi dengan Kelelahan Kerja Perawat

Di Rumah Sakit Permata Hati Duri Kecamatan Mandau

Kabupaten Bengkalis Tahun 2019

\begin{tabular}{|c|c|c|c|c|c|c|c|c|c|}
\hline \multirow{3}{*}{ No } & \multirow{3}{*}{ Variabel uji } & \multicolumn{6}{|c|}{ Kelelahan Kerja } & \multirow{3}{*}{$\begin{array}{c}\mathbf{P} \\
\text { value }\end{array}$} & \multirow{3}{*}{$\begin{array}{c}\text { POR } \\
95 \% \mathrm{CI}\end{array}$} \\
\hline & & \multicolumn{2}{|c|}{ Rendah } & \multicolumn{2}{|c|}{ Tinggi } & \multicolumn{2}{|c|}{ Total } & & \\
\hline & & $\mathbf{N}$ & $\%$ & $\mathbf{n}$ & $\%$ & $\mathbf{N}$ & $\%$ & & \\
\hline \multirow[t]{4}{*}{1} & Status gizi & & & & & & & & \\
\hline & Gizi buruk & 2 & $33,3 \%$ & 4 & $66,7 \%$ & 6 & $100 \%$ & \multirow{3}{*}{1,000} & \multirow{3}{*}{$\begin{array}{c}0,864 \\
(0,146- \\
5,105)\end{array}$} \\
\hline & Gizi baik & 22 & $36,7 \%$ & 38 & $63,3 \%$ & 60 & $100 \%$ & & \\
\hline & Jumlah & 24 & $36,4 \%$ & 42 & $63,6 \%$ & 66 & $100 \%$ & & \\
\hline
\end{tabular}

Berdasarkan tabel 6 diatas, diketahui dari 8 responden yang memiliki status gizi buruk, $5(62,5 \%)$ diantaranya mengalami kelelahan kerja tinggi. Dari 58 responden yang memiliki status gizi baik, $37(63,8 \%)$ diantaranya mengalami kelelahan kerja tinggi.
Hasil uji statistik menggunakan $C h i$ square diperoleh nilai $\mathrm{P}$ value $=1,000>$ $\mathrm{a}_{0,05}$, maka ha diterima dan ho ditolak, dapat disimpulkan bahwa tidak ada hubungan antara status gizi dengan kelelahan kerja perawat di Rumah Sakit Permata Hati Duri Kecamatan Mandau Kabupaten Bengkalis tahun 2019. 
Penelitian ini sejalan dengan penelitian Dyah (2013), hasil penelitian menunjukkan tidak ada hubungan antara status gizi dengan kelelahan kerja yaitu $\mathrm{P}$ value $=0,84>a_{0,05}$. Hasil ini menunjukkan tidak ada perbedaan antara status gizi uruk dan baik terhadap kelelahan kerja.
Menurut analisa peneliti bahwa status gizi tidak menjadi salah satu hal penyebab kelelahan kerja pada perawat. Dalam penelitian ini diperoleh hasil bahwa tidak ada hubungan antara status gizi dengan kelelahan kerja perawat, karena perawat tidak perlu memiliki fisik yang kuat tapi cenderung memiliki tipe pekerjaan yang monoton.

\section{Hubungan Antara Riwayat Penyakit Dengan Kelelahan Kerja}

Tabel 7

Hubungan Riwayat Penyakit dengan Kelelahan Kerja Perawat

Di Rumah Sakit Permata Hati Duri Kecamatan Mandau

Kabupaten Bengkalis Tahun 2019

\begin{tabular}{|c|c|c|c|c|c|c|c|c|c|}
\hline \multirow{3}{*}{ No } & \multirow{3}{*}{ Variabel uji } & \multicolumn{6}{|c|}{ Kelelahan Kerja } & \multirow{3}{*}{$\begin{array}{c}\mathbf{P} \\
\text { value }\end{array}$} & \multirow{3}{*}{$\begin{array}{c}\text { POR } \\
95 \% \text { CI }\end{array}$} \\
\hline & & \multicolumn{2}{|c|}{ Rendah } & \multicolumn{2}{|c|}{ Tinggi } & \multicolumn{2}{|c|}{ Total } & & \\
\hline & & $\mathbf{N}$ & $\%$ & $\mathbf{n}$ & $\%$ & $\mathbf{N}$ & $\%$ & & \\
\hline \multirow[t]{4}{*}{1} & $\begin{array}{l}\text { Riwayat } \\
\text { penyakit }\end{array}$ & & & & & & & & \\
\hline & $\begin{array}{c}\text { Ada riwayat } \\
\text { penyakit }\end{array}$ & 7 & $33,3 \%$ & 14 & $66,7 \%$ & 21 & $100 \%$ & \multirow[t]{3}{*}{0,940} & \multirow{3}{*}{$\begin{array}{c}0,824 \\
(0,277- \\
2,447)\end{array}$} \\
\hline & $\begin{array}{c}\text { Tidak ada } \\
\text { riwayat } \\
\text { penyakit }\end{array}$ & 17 & $37,8 \%$ & 18 & $62,2 \%$ & 45 & $100 \%$ & & \\
\hline & Jumlah & 24 & $36,4 \%$ & 42 & $63,6 \%$ & 66 & $100 \%$ & & \\
\hline
\end{tabular}

Berdasarkan tabel 14 diatas, diketahui dari 21 responden yang ada riwayat penyakit, $14(66,7 \%)$ diantaranya mengalami kelelahan kerja tinggi. Daari 45 responden yang tidak ada riwayat penyakit, $28(62,2 \%)$ diantaranya mengalami kelelahan kerja tinggi.

Hasil uji statistik menggunakan $C h i$ square diperoleh nilai $\mathrm{P}$ value $=0,940>$ $\mathrm{a}_{0,05}$, maka ha diterima dan ho ditolak, dapat disimpulkan bahwa tidak ada hubungan antara riwayat penyakit dengan kelelahan kerja perawat di Rumah Sakit Permata Hati Duri Kecamatan Mandau Kabupaten Bengkalis tahun 2019. Penelitian ini sejalan dengan penelitian Sriwahyuni (2015), bahwa hasil penelitian menunjukkan tidak adanya hubungan antara riwayat penyakit dengan kelelahan kerja dengan $\mathrm{P}$ value $=$ $0,588>a_{0,05}$, maka tidak terdapat hubungan antara riwayat penyakit dengan kelelahan kerja. 
Menurut asumsi peneliti bahwa sebagian besar perawat tidak memiliki penyakit kronis, sehingga kondisi fisik perawat berada dalam posisi normal. Walaupun tubuh melakukan suatu pekerjaan, tubuh masih mampu melaksanakan pekerjaan tersebut sehingga tidak terjadi kekurangan suplay oksigen ke otot yang nantinya dapat mempercepat terjadinya kelelahan.

\section{KESIMPULAN}

Dari hasil penelitian yang dilakukan oleh peneliti tentang hubungan jenis kelamin, usia, status perkawinan, masa kerja, shift kerja, status gizi dan riwayat penyakit dengan kelelahan kerja perawat di Rumah Sakit Permata Hati Duri Kecamatan

Mandau Kabupaten Bengkalis tahun 2019, didapat kesimpulan :

1. Tidak terdapat hubungan antara jenis kelamin responden dengan kelelahan kerja perawat di di Rumah Sakit Permata Hati Duri Kecamatan Mandau Kabupaten

Bengkalis tahun 2019 dengan nilai $\mathrm{P}$ value $=0,523>\mathrm{a}_{0,05}$.

2. Terdapat hubungan antara usia responden dengan kelelahan kerja perawat di di Rumah Sakit Permata Hati Duri Kecamatan Mandau Kabupaten Bengkalis tahun 2019 dengan nilai $\mathrm{P}$ value $=0,000<\mathrm{a}_{0,05}$
3. Terdapat hubungan antara masa kerja responden dengan kelelahan kerja perawat di di Rumah Sakit Permata Hati Duri Kecamatan Mandau Kabupaten Bengkalis tahun 2019 nilai $\mathrm{P}$ value $=0,048<$ $\mathrm{a} 0,05$

4. Terdapat hubungan antara shift kerja responden dengan kelelahan kerja perawat di di Rumah Sakit Permata Hati Duri Kecamatan Mandau Kabupaten Bengkalis tahun 2019 dengan nilai $\mathrm{P}$ value $=0,048<a_{0,05}$

5. Tidak terdapat hubungan antara status gizi responden dengan kelelahan kerja perawat di di Rumah Sakit Permata Hati Duri Kecamatan Mandau Kabupaten

Bengkalis tahun 2019 dengan nilai $\mathrm{P}$ value $=0,523>\mathrm{a}_{0,05}$

6. Tidak terdapat hubungan riwayat penyakit responden dengan kelelahan kerja perawat di di Rumah Sakit Permata Hati Duri Kecamatan Mandau Kabupaten

Bengkalis tahun 2019 nilai P value $=0,940>a_{0,05}$

7. Terdapat hubungan status perkawinan penyakit responden dengan kelelahan kerja perawat di di Rumah Sakit Permata Hati Duri Kecamatan Mandau Kabupaten Bengkalis tahun 2019 nilai P value 


$$
=0,000<a_{0,05}
$$

\section{DAFTAR PUSTAKA}

Aditama, C. (2010). Manajemen Administrasi Rumah Sakit. UI-Press : Jakarta

Angouw,Toar.A.,dkk (2016). Perbedaan

Tingkat Kelelahan Kerja Pada

Perawat Shift Kerja Pagi, Shift Kerja

Sore Dan Shift Kerja Malam Di

Ruangan Rawat Inap Rsu Gmim

Tomohom. Fakultas Kesehatan

Masyarakat Universitas Sam

Ratulangi Manado. Vol.5

Anjar Permatasari dkk. (2017) Faktor

Yang Berhubungan Dengan

Kelelahan Kerja Karyawan Di

Matahari Departmentstore Cabang

Lippo Plaza Kendari. Vol. 2

Arlina. (2016). Pengaruh beban erja terhadap kelelahan kerja pada perawat di ruang rawat inap rumah sakit tentara tk. IV010702 Binjai tahun 2016. Vol. 3

Budiono, AMS dkk. (2015). Bunga Rampai HIPERKES \& KK. Badan Universitas Diponegoro Semarang.

Cesilia Watania dkk. (2018). Perbedaan Tingkat Kelelahan Kerja Perawat Di Unit Gawat Darurat Dan Poliklinik Rumah Sakit Umum Gmim Pancaran Kasih Manado. Vol.6.
Dita Andini Dwi Pratiwi dkk. (2017). Gambaran Tingkat Kelelahan Kerja Perawat di Ruang Perawatan Intesif. Jurnal Jurusan Keperawatan. Vol.3.

Deivy Tenggor dkk. (2019). FaktorFaktor Yang Berhubungan Dengan Kelelahan Kerja Pada Perawat Diruang Rawat Inap Rumah Sakit Umum GMIM Pancaran Kasih Manado. Vol. 7

Eko Nurmianto. (2009). Ergonomi, Konsep Dasar \& Aplikasinya. Guna Widya. Jakarta.

Gadhiwu Lidia,dkk. (2015). Analisis Beberapa Faktor Penyebab

Kelelahan Kerja Tenaga Bongkar Muat Pelabuhan Samudra Belitung. Jurnal Kesehatan Masyarakat. Universitas Sam Ratulangi.

Herlambang, S. (2016). Manajemen Pelayanan Kesehatan Rumah Sakit, Yogyakarta; Gosyen publishing.

Inta Hestya dkk. (2012). Hubungan Kerja Shift Terhadap Kelelahan Perawat Di Instalasi Rawat Inap RSUD Dr. Sayidamin Magetan Tahun 2012. Jurnal kesmas jurusan kesehatan masyarakat lingkungan kampus magetan.

Januar Atiqoh dkk (2014). FaktorFaktor Yang Berhubungan Dengan Kelelahan Kerja Pada Pekerja Konveksi Bagian Penjahitan CV. 
Aneka Garment Gunungpati

Semarang. Vol. 2

Kusdi Raharjo. (2013). Teori Organisasi

Dan Administrasi. Salemba

Humanika. Jakarta

Lidya Monica. (2010). Gambaran

Keelahan Kerja Pada Penjahut Di

Pasar Petisah Kecamatan Medan

Baru Kota Medan. Vol 3.

Lientje Setyawati K.Maurits. (2013).

Selintas Tentang Kelelahan Kerja.

Amara Books. Yogyakarta.

Maghfiroh, S dan Mifbakhuddin. (2015).

Hubungan Toleransi Stress, Shift

Kerja dan Status Gizi dengan

Kelelahan Kerja pada Perawat di

IGD dan ICU (Studi di RSI Sultan

Agung Semarang). Jurnal Kesehatan

Masyarakat Indonesia 10(2):46-53.

Nur aini. (2018). Hubungan Shift Kerja

Dengan Kelelahan Kerja Pada

Perawat Di Instalasi Rawat Inap Di

Rumah Sakit Herna Medan Tahun 2018. Vol. 4

Peraturan Mentri Kesehatan Indonesia nomor 56 tahun 2014. Klasifikasi dan Perizinan Rumah Sakit

Sugiyono. (2013). Metodologi Penelitian

Kuantitatif, Kualitatif Dan $R \& D$.

Alfabeta. Bandung

Suma'mur P,K.,MSc. (2013). Higiene

Perusahaan dan Kesehatan Kerja

(HIPERKES). CV Sagung Seto. Jakarta.
Sunaryo. W. (2014). Ergonomi dan K3.

Bandung ; Rosdakarya

Srimadentika. (2018). Faktor-Faktor Yang Berhubungan Dengan Kelelahan Kerja Perawat Di Rumah Sakit Horas Insani Pematangsiantar. Vol 5.

Tarwaka. 2014. Ergonomi Industri: Dasar-dasar Pengetahuan Ergonomi dan Aplikasi di Tempat Kerja. Harapan Press. Solo.

Tim Skripsi Prodi IKM. (2018). Buku

Panduan Skripsi. STIKes Hang Tuah Pekanbaru

Triefna L.M Thio dkk. (2016).

Hubungan Antara Stress Kerja,

Iklim Kerja, Hubungan Kerja

Dengan Beban Kerja Di Rawat Inap

Rumah Sakit Bethesda Gmim

Tomohon. Vol 4

Riza Desima. (2013). Tingkat stress kerja perawat dengan perilaku caring perawat. Vol. 4

Rizki Maharja. (20150. Analisis Tingkat Kelelahan Kerja Berdasarkan Beban Kerja Fisik Perawat Di Instalasi Rawat Inap Rsu Haji Surabaya. Vol.4

Republik Indonesia.

(2014)

Undangundang Keperawatan No.38 tahun 2014.

Vilia Adelina. (2013). Faktor-FaktoYang Berhubungan Dengan Kelelahan Kerja Pada Perawat Di Instalasi 